\title{
The hands of Donald Trump
}

\section{Entertainment, gesture, spectacle}

\author{
Kira HaLl, University of Colorado Boulder \\ Donna M. Goldstein, University of Colorado Boulder \\ Matthew Bruce Ingram, University of Texas at Austin
}

Commentators from a broad range of perspectives have been at pains to explain Donald Trump's transition from billionaire businessman to populist presidential candidate. This article draws on cultural anthropology, linguistic anthropology, and rhetorical theory to argue that the success of Trump's candidacy in the 2016 Republican primary was in part due to its value as comedic entertainment. We examine the ways that Trump's unconventional political style, particularly his use of gesture to critique the political system and caricature his opponents, brought momentum to his campaign by creating spectacle. Post-structuralist and neo-Marxist scholars have asserted that late capitalism values style over content: Trump took this characteristic to new heights. The exaggerated depictions of the sociopolitical world that Trump crafts with his hands to oppose political correctness and disarm adversaries accrue visual capital in a mediatized twenty-first-century politics that is celebrity driven.

Keywords: comedy, entertainment, gesture, humor, depiction, politics, spectacle

Donald Trump Jr.s description of his father as a "blue-collar billionaire" during the 2016 Republican primary season highlighted a contradiction that has puzzled commentators on both sides of the political spectrum since the beginning of Trump's rise in the election polls: How does a businessman situated in the uppermost tier of American wealth capture the allegiance of the working classes? Academics, journalists, and other writers have been at pains to explain the early pollster finding that a billionaire developer became the favored choice of a population whose economic interests differed radically from his own. Linguist George Lakoff (2016) attributes Trump's popularity among conservatives to his projection of a moral universe that valorizes punishment and individualism and thus resonates with a "Strict Father

This work is licensed under the Creative Commons | ( ) Kira Hall, 
worldview." Anthropologist Tanya Luhrmann (2016) draws from ethnographic scholarship on religion to explain Trump's appeal among followers as having less to do with political anger than with the contribution that Trump's taboo-violating behavior offers to "religious imagination." Sociologist Arlie Russell Hochschild (2016) narrates the ways that Tea Party supporters are motivated by a sense of unfairness in a time of economic stagnation. J. D. Vance (2016), bestselling author of Hillbilly elegy, explains Trump's appeal among impoverished white Appalachians as based in a concern with gun ownership in a destitute environment that denies rural populations other forms of political agency. As the November 2016 national election nears, commentators remain puzzled as to how a class of struggling wage earners, as Trump's base is often described, came to accept the populist discourse of a man who called the money he received from his father in 1978 to start his career a "small loan of a million dollars."

Our analysis of Trump's rise in the 2016 Republican primary season suggests that a focus on economic distance between Trump and his voting base is misguided. Not only is Trump's reach apparently much broader than initially suggested in pollster and media assessments (Silver 2016), his historical uniqueness as the Republican presidential nominee lies not in wealth but in lack of political experience. We argue, in contrast to these accounts, that Trump's campaign to become the Republican nominee was successful because it was, in a word, entertainingnot just for the white rural underclass, not just for conservatives, but also for the public at large, even those who strongly oppose his candidacy. Whether understood as pleasing or offensive, Trump's ongoing show was compelling. Our analysis thus refrains from defining segments of the population as economically, socially, or psychologically vulnerable to Trump's messaging and instead explores why we are all vulnerable. Many good analyses offer insights on Trump's popular appeal, and we draw on some of these discussions here. But we believe it is also important to consider the specifics of Trump's entertainment value-that is, how Trump's comedic media appearances over the course of the Republican primary season built momentum in a celebrity and mediatized culture. Social scientists and humanities scholars from both neo-Marxist and poststructuralist perspectives have long asserted that late capitalism values style over content. Trump's rising popularity during his journey from candidate to Republican presidential nominee provides a strong example of this claim.

Scholars in a variety of fields have considered entertainment as a value by positioning it as key to comprehending class relations. Historian Peter Burke (1978) highlights the role of entertainers such as ballad singers, jugglers, puppet masters, and comedians among the peasantry in the sixteenth through eighteenth centuries. He offers the important insight that these performers, by attracting the attention of audiences across the class spectrum, enabled mutual permeability between elite and popular culture. Similarly, philosopher and literary critic Mikhael Bakhtin's (1984) Stalin-era writings on the French Renaissance novelist Rabelais illuminate the power of carnivalesque entertainment: fools and clowns subvert the social order through acts of parody, poking vulgar fun at the mystique of political rulers and stirring rebellion in their audiences. Anthropologist Anton Blok (2001) draws from these discussions to develop a structuralist argument regarding the historical significance of a broad category of "infamous occupations" that includes criminals 
as well as entertainers. For Blok, the position held by reviled professionals in times of political transition is paradoxical: "liminal and out of place, defining and credited with magical power, marginalized and yet part of the community, despised and indispensable" (Blok 2001: 65). Once Peter Stallybrass and Allon White (1986) extended Bakhtin's carnivalesque to broader modes of cultural and class analysis, entertainment became a common anthropological trope for examining contestations of social hierarchy in everyday life, particularly with respect to humor, joking, and laughter.

These examples reveal how street performers, clowns, criminals, or jokers may become popular-and valuable - precisely because of their skill at entertaining. In the liminal space of comedic entertainment, distinct identities of "high" and "low" culture may remain in the interpretation of verbal and gestural form, but viewers laugh, even if not for the same reason. Humorous performance, as Erving Goffman $(1959,1961)$ once argued, is protected from the scrutiny that would be applied in other discursive domains (cf. Chun 2004; Jaffe 2000). In this sense, humor functions as a kind of containment strategy (Irvine 2011; Fleming and Lempert 2011), enabling its users to invoke taboo topics without breaching the norms that define these topics as toxic (Goldstein [2003] 2013). Although some audiences may interpret particular forms of entertainment as bad taste, it is also seen as bad taste to critique a fun-loving enterprise. It is hard to critique a clown: we are too busy laughing. We must therefore consider the protective benefits of entertainment value: entertainers have license to disobey rules. As anthropologists have long known, liminal spaces of time and affect such as carnival are special in that rules of ordinary everyday life do not apply. Yet even if carnival suspends social rules temporarily, its subversive potential is often lost in the return to everyday life: at the end of the day, it may preserve the very class, race, and gender values it inverts while in motion (Goldstein [2003] 2013; Scheper-Hughes 1992). Entertainment involves a densely mediatized apparatus that early scholarship on carnival did not consider, but in this sense it is similar.

Drawing on cultural anthropology, linguistic anthropology, and rhetorical theory, we consider how Trump elevates his entertainment value by crafting comedic representations of his political opponents as well as himself. These representations take the form of a kind of embodied performance primarily discussed by scholars studying gesture. Characterized by several interrelated terms that include bodily quoting (Keevallik 2010), transmodal stylizations (Goodwin and Alim 2010), full body enactments (Mittelberg 2013), gestural reenactments (Sidnell 2006), and pantomime (Streeck 2008a), these bodily acts involve the dramaturgical replaying of an actual or imagined event, action, or behavior (cf. Goffman 1974), often by assuming another's alleged subjectivity. They are most clearly seen in Trump's impersonations of political opponents at campaign rallies. Through the use of gestural methods, Trump metonymically reduces others to laughable portrayals while elevating himself. During the Republican primaries, some of Trump's more notorious gestural enactments-as we call them here-included contorted wrist and facial movements when rebuking a disabled reporter; downward hand chops and sidewise throat slices to convey how ISIS has treated American citizens; and a slumped torso with closed eyes to depict Republican competitor Jeb Bush. Many of these enactments were repeated across multiple campaign speeches and became 
emblems of the political persona that Trump presented to his electorate. The media's conflicted response to the social meaning of these bodily displays, together with Trump's easy deniability of what he intended by them, suggests that comedic gesture may accomplish ideological work that exceeds even what can be conveyed in the already protected category of verbal humor.

Trump's enactments received unprecedented attention during the Republican primaries by inspiring countless news discussions, video compilations, and comedy skits, many of which we reviewed for the writing of this article. Together we observed twenty-seven hours of video data to make the claims expressed here, with nineteen of those hours coming from campaign speeches delivered in sixteen different locations. Perhaps one answer to why Trump's behavior appears atypical for a presidential candidate is that it deviates from the gestural prescriptivism that has dominated the American political arena. For instance, Jürgen Streeck's (2008b) analysis of gestures used by Democratic presidential candidates during the 2004 primary season reveals that candidates avoided using pictorially oriented depictive gestures (also called iconics in McNeill's [1992] taxonomy). For Streeck, this avoidance invites comparison with prescriptions articulated by Roman orator Quintilian in the first century $\mathrm{CE}$, who characterized gestures that provide visual displays as theatrical and lacking rhetorical gravitas. What are acceptable for use by the rhetorician are what gesture scholars sometimes call interactive or pragmatic gestures (Bavelas et al. 1992; Kendon 2004), hand movements such as beats or points that do not depict the social world but rather accentuate or illustrate the rhetorical structure of a speech. As Robin Tolmach Lakoff (1992) suggests in her analysis of George H. W. Bush's transition to a limited set of these gestures during the 1988 campaign, presidential advisors instruct their candidates on techniques of bodily comportment as well as speech. Pragmatic gestures are now the subject of a growing body of research on political style, which includes analyses of Barack Obama's precision-grip (Lempert 2011) and Howard Dean's indexical point (Streeck 2008b). But the depictive gestures deployed by Trump-especially the type that caricatures opponents by embodying a behavior or activity associated with them-rarely surface in the same literature. How do we explain the success of Trump's divergence from what appears to be normative gestural behavior for politicians seeking the Oval Office?

We make sense of Trump's gestural repertoire by viewing it as part of a comedic political style that accrues entertainment value as it opposes the usual habitus associated with US presidential candidates. When used in coordination with verbal strategies similarly designed to lampoon opponents, Trump's enactments craft essentialized characterizations of identity categories that simultaneously cast their members as problematic citizens, whether Democrats, disabled, lower class, Muslim, Mexican, or women. These depictive gestures operate cross-modally to signal to Trump's base that he challenges what is widely viewed as the political establishment's debilitating rhetoric of political correctness. When Trump promises to tell the truth (Muslims are terrorists; some women are uglier than others; Mexicans are rapists), he aligns himself with opposition to political correctness, with a stance that rejects rhetorical caution regarding minority religions, genders, and ethnicities. Yet as entertainment, his gestures intensify the force of his words, attracting and holding the attention of the wider public as they dominate the news cycle. When framed 
against the more restrained style of old school politics, Trump's gestures serve him well, particularly in a mediatized and visually oriented twenty-first-century politics that is celebrity driven. If the roles of celebrity and politician have merged in the public sphere, as a voluminous literature suggests (e.g., Brummett 2008; Duffy and Page 2013; Hariman 1995; Lempert and Silverstein 2012; West and Orman 2003; Wheeler 2013), entertainment forms once associated with genres such as stand-up comedy-including the exaggerated bodily characterizations of the sociopolitical world that Trump deploys to diminish his adversaries-now make good political sense. Gesture helps create the excess necessary for comedic routine.

We argue Trump's unconventional political style receives attention that helps rather than harms his candidacy because it is absorbed as entertainment by a heavily mediatized public sphere. Trump's embodiment may be incongruous with how strong political embodiment is normatively understood, but its dense link to entertainment now brings voters along with viewers. The electoral allure of Trump's "grotesque body" - to borrow a phrase used by Bakhtin (1984) to describe the subversive humor of the medieval marketplace-suggests that scholarship on society as well as gesture may benefit from a deeper consideration of comedic entertainment as an important social vector at this transitional moment in US political history. We have found it productive to analyze the complexities of a billionaire mogul's political success through the three-way lens of entertainment, gesture, and spectacle.

\section{Entertainment}

Sociologist Paul Fussell (1992) suggested two decades ago in his acclaimed text on the American class system that the most important characteristic of the top-earning super rich is that they remain "out of sight" (27). Yet Fussell wrote before the emergence of the current celebrity culture, where the super rich are very much "in sight" across television, radio, satellite, and social media. Trump, who belongs to this billionaire culture, is a mastermind at keeping his celebrity status frontline news, a talent he exercised for decades as a corporate millionaire in the public eye. In a mediatized environment dependent on celebrity news, a politician can now be given the same treatment as a celebrity and become "the collective fetish of the masses... for whom every tidbit about the celebrity's physical, sartorial, characterological, discursive, and other biographical features is worthwhile to their attentive collection and appreciation" (Lempert and Silverstein 2012: 8). In the case of Trump, however, rather than a politician turned celebrity, we have a celebrity turned politician. If Trump is a "rule breaker," as the front cover of Time (2016) proclaimed, it is because he used his craft as an entertainer to forge a new hybrid of politics and comedy. Trump is certainly not the first celebrity entertainer to become a politician, and his ascendency in the Republican primaries is in many ways unsurprising given the ongoing hybridization of politics and entertainment in contemporary US society. But Trump's dense use of a derisive form of comedic entertainment to attract media attention-no matter how negative that media attention may be-is a strategy that previous entertainer candidates such as Ronald Reagan did not pursue.

The entertainment dimension of Trump's resume has not gone unnoticed by his critics, with some labeling him an entertainer in the hope of discrediting his 
candidacy. "Showtime is over everybody, we are not electing an entertainer-inchief," pronounced New Jersey governor Chris Christie in a speech at Saint Anselm College (before he became a Trump supporter). Obama chastised the media during a press briefing for their delicate treatment of Trump: "This is not entertainment; this is not a reality show." Journalists and commentators have noted Trump's entertainment appeal for years (Singer 1997; Taibbi 2016), with editorial cartoonists depicting Trump variously as clown, jester, King Kong, Lone Ranger, juggler, and master of ceremonies (US News 2016). Indeed, a cartoon on the front cover of the New Yorker (Blitt 2016) caricatures Trump as a political entertainer on a television screen, his waving hands and wide mouth earning the concerned gaze of five presidential icons-Kennedy, Lincoln, Teddy Roosevelt, FDR, and finally Washington, who covers his eyes with his hands. Seen in relation to presidents in the predigital era, Trump epitomizes twenty-first century visual excess and hyperbole.

In fact, Trump used his entertainer credentials during the Republican primaries to deflect criticism over his verbal behavior. "Many of those comments are made as an entertainer," he responded when questioned about the tone of his campaign (On the Record 2015). Later in the same interview, Trump defended his behavior by linking it to his performance on the reality-TV game show The Apprentice, where his role as tough love boardroom businessman dramatized a corporate bully who trains apprentices to become cutthroat entrepreneurs. Trump's performance delivered its punch by denigrating contestants, and this became central to the show's appeal. His celebrity entertainer status thus lent him deniability during the primaries: relations between form and meaning established in one discursive field (entertainment) excused behavior in another (politics). That Trump's political personality seemed to mimic his Apprentice persona suggests that the genre of reality TV may succeed in manufacturing "authenticity" via the magical qualities that derive from the form's ambiguity. Reality TV is of course not reality per se but rather a staged parody of reality delivered by the culture industry (Andrejevic 2004). It is magical, in the sense of early anthropology, because it contains within itself the contradictory frames of existence expressed by its name: reality and television. "Positivist" viewers who believe in its reality and "savvy" viewers who recognize its contrived nature are both able to respond to the entertainment value of the genre (Andrejevic 2004). The same ambiguity offered a peculiar advantage to Trump during the Republican primaries: Was Trump's bullying behavior reality or performance? His claim of an entertainer identity protected him from the media firestorms that followed other candidates when they engaged in comedic derision. Those who tried to defeat Trump using Trump's methods could not succeed. Florida senator Marco Rubio even felt compelled to register a rather dramatic public apology after he joked about the small size of Trump's hands (and by implication the small size of his penis) at a campaign rally in Roanoke, Virginia. A long-term politician, Rubio was not protected by the entertainer magic that shielded his adversary.

Over the last several decades, the United States has experienced a noticeable intensification of celebrity culture in politics. Ronald Reagan, "the Teflon President," was a Hollywood celebrity whose life story also differed from the traditional political narrative. His campaign accelerated the use of advertising techniques based on "image marketing" so that "democracy itself [became] style" (Ewen 1988: 268). The political system that supports Trump is much closer to entertainment than what 
was experienced in the Reagan years, not merely in the way it awards politicians celebrity status but also in the way it creates politicians out of celebrities. Certainly we have seen precursors to Trump in the gubernatorial rise of entertainers like Hollywood actor Arnold Schwarzenegger and professional wrestler Jesse Ventura. But image consumption in the Trump era operates at a very different scale, exploiting the stylized techniques associated with comedic entertainment as political platform.

To watch Trump perform a stump speech is to experience something like standup comedy. His words, gestures, repetitions, and interactive style tag his routines as comedic, if also crude and bawdy. Indeed, prominent comedians such as Samantha Bee, Trevor Noah, and John Oliver have themselves noted that Trump's routines mirror a comedic format (see, for instance, The Daily Show 2016). His performances recall the signature elements of stand-up introduced to the American public in the 1960s and 1970s by comedians such as Lenny Bruce, George Carlin, Carl Reiner, Mel Brooks, and Richard Pryor, all recognized as comedic geniuses who employed taboo language to create comedy (Seizer 2011) and to insinuate the abject (Limon 2000). At a political rally in Grand Rapids, Michigan, Trump questions why Clinton arrived late to the previous night's debate stage after a break. "Where did she go?" he asks the crowd. "I thought she quit, I thought she gave up! I know where she went and it's too disgusting! Wasn't this a weird deal?" Minutes later, Trump reminds the audience that Clinton "got schlonged" by Obama in the last primary, using the Yiddish word for penis to keep risqué talk in play. In a speech in Raleigh, North Carolina, Trump abruptly interrupts a woman as she asks "I was wondering what you would say to President Obama ..." with the reply "You're fired!" The performative has a vulgar emphasis on the [f] (see Figure 1a) as he throws his index finger forward to make the shape of a gun (see Figure 1b).

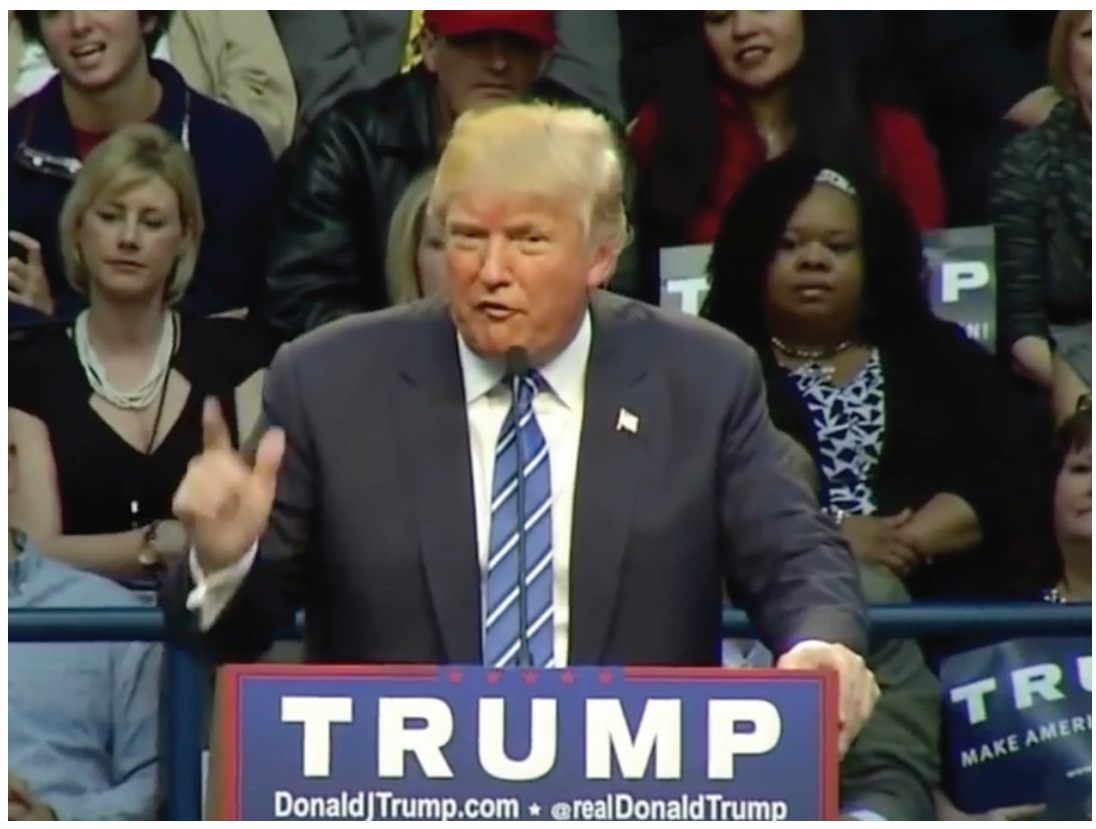

Figure 1a: Trump’s Pistol Hand gesture (start), CBS North Carolina. 


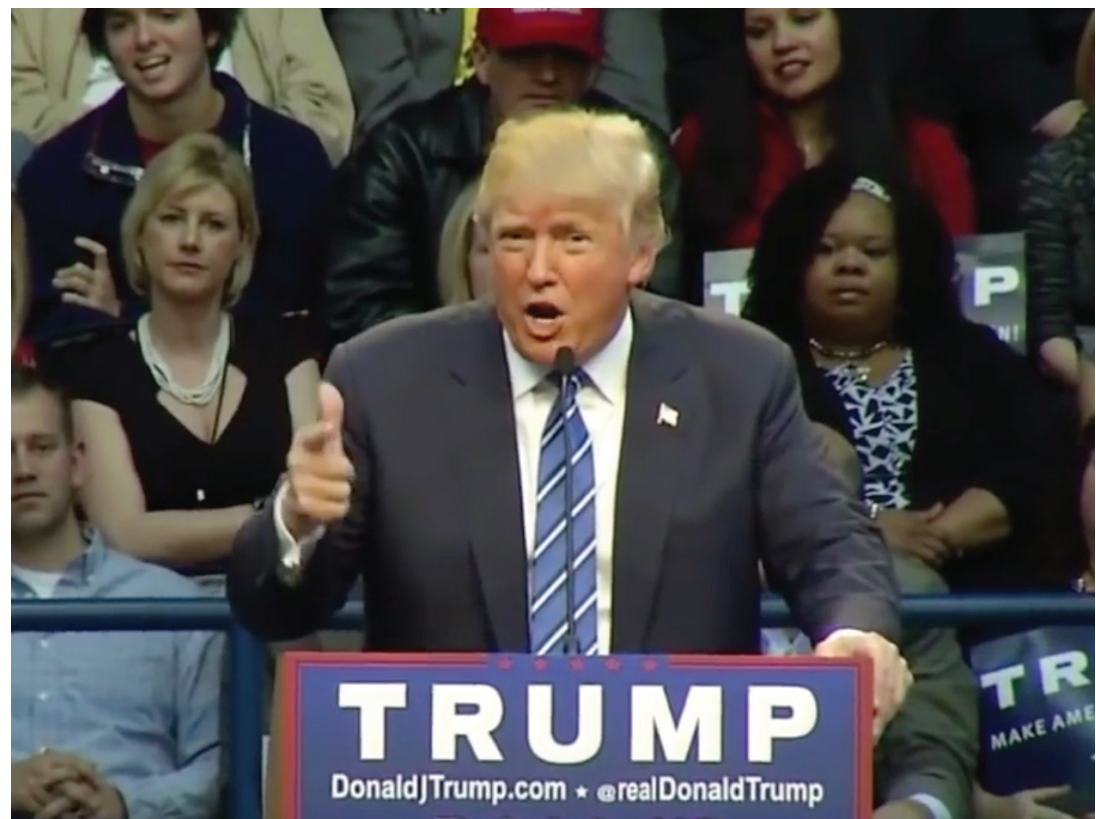

Figure 1b: Trump's Pistol Hand gesture (finish), CBS North Carolina.

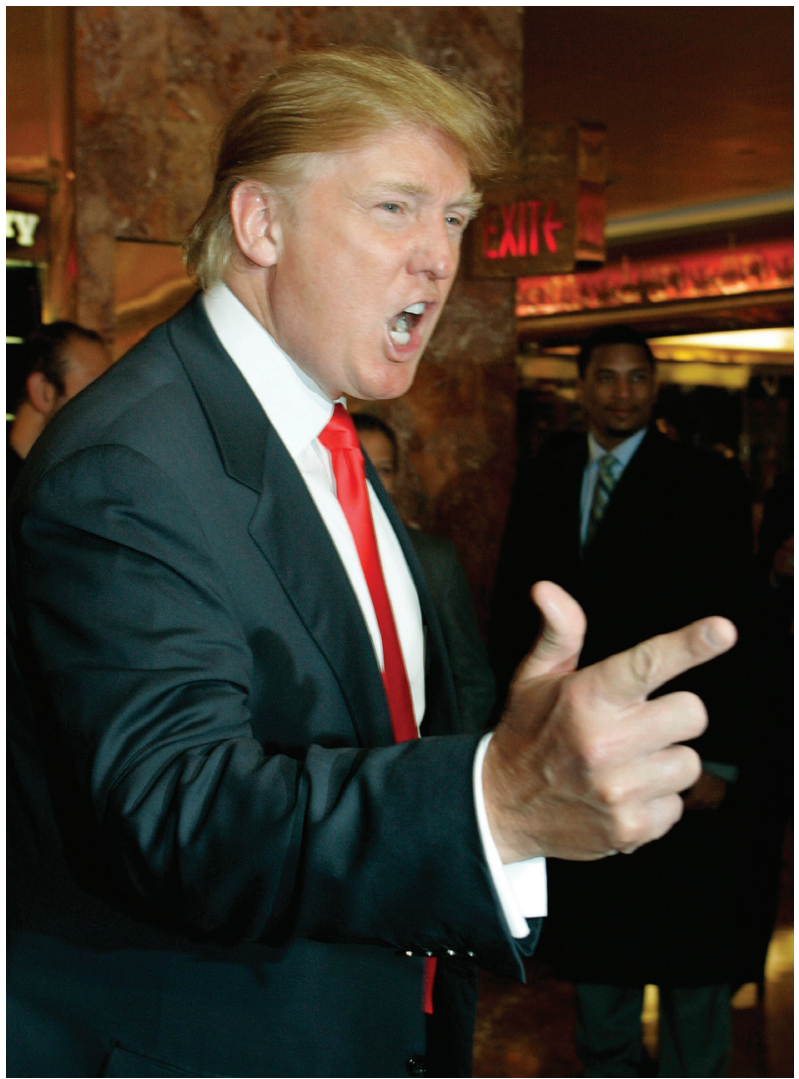

Figure 2: Trump's Pistol Hand gesture, The Apprentice (2006), Associated Press Images. 
This is Trump's infamous pistol hand gesture, the one he also used on The Apprentice to fire unworthy contestants (see Figure 2). The crowd gets the intertextuality and irrupts explosively into cheers, whistles, and screams.

This is not the usual stuff of stump speeches but rather comedic performance. At Trump's campaign rallies, a New York billionaire's routine built on "bad taste" is displayed in carnivalesque fashion to a self-selected audience that understands his humor as funny. Literary scholar John Limon's (2000) understanding of comedy as "the resurrection of your father as your child" - that is, the performance of punishing father and naughty son all at once-may in part explain the hilarity of Trump's routines, particularly to those who subscribe to Lakoff's (2016) analytics of the Strict Father family. Laughing with Trump, supporters are empowered; their differences with respect to social class or economic interests appear trifling. One need only remember how America wanted to have a beer with George W. Bush and how this small feature about the man increased his likeability. Laughter has always been understood as a weapon of the weak (Scott 1985; cf. Goldstein [2003] 2013), but it is perhaps also a weapon of the powerful. Trump makes people laugh, even if they are not laughing at the same thing. Media broadcasts of public reception spotlight some who laugh because they find Trump's daily insults funny and others who laugh in disbelief and outrage. Yet both sides seem equally engaged by the question: "What did Trump say today?" Trump's material is based on strong image projection ("Make America great again"; "Be a winner"), comedic gesture (mimetic enactments, histrionic facial expressions, rolling eyes, torso shrugs), sarcasm ("yeah, right"), repetition of packaged comedic routines (planes flying overhead at campaign rallies used as props to joke about military opponents), adversarial stance (anti-political correctness), staged rituals of masculinity and femininity (competitive one-upmanship involving braggadocio and beauty), and the bullying of opponents ("Look at that face"; "Jeb is a boring guy, basically a loser"). If viewers read Trump as an entertainer, it is because of these performances, where insults and gestures are produced in excess and often coordinated to enhance comedic effect.

We have never seen a presidential candidate quite like this one. Nothing Trump did during the Republican primaries moved his supporters away from him. Much ink has been spilled over the negative aspects of Trump's person-his ignorance, unpresidentiality, misogyny, racism, unpredictability - but no one seems able to explain why his popularity did not plummet, even after he told the nation that his hands were big and his genitals fine. Politicians have been ruined by much less. Gerald Ford was labeled a "klutz" after slipping on the stairs of Air Force One. Al Gore was ridiculed for sighing and rolling his eyes in debates with George W. Bush. Dan Quayle was deemed "stupid" because he had to learn from a sixth grader that potato is not spelled with "e." Howard Dean was recast as "hysterical" because of a scream he delivered to his supporters after a third-place finish in the Iowa primaries ("Yeeeeeeeeaaaaaahhhh!!"). But would any of these actions have damaged Trump's candidacy? Our argument is precisely that it is the style of Trump-his speech, his gestures, his comedic timing - that brings entertainment value and explains his political success. We agree with Dave Eggers (2016) in The Guardian when he says: "The moment [Trump] ceases to entertain-to say crazy shit-he will evaporate." Indeed, if we break from our temporal frame of the Republican 
primary season and flash forward to the federal election, it does appear that a more restrained Trump has fallen in popularity.

With visuals of Trump widely distributed across diverse media, the nation has now viewed so many instances of unpresidential behavior that almost anything seems acceptable. This development has led some commentators to revisit "the Howard Dean moment" in an effort to understand how the comparatively minor offense of a rallying cry could destroy a presidential campaign. Media scholar Robert Thompson asks in a recent documentary on fatal campaign blunders (History Channel 2016): What must Howard Dean be thinking now? Dean's scream allegedly made him appear high strung, even hysterical. But did Dean really sound so out of control? Weren't his poll numbers already fading? Jürgen Streeck (2008b) argues that Dean's mistake was actually not the scream at all but rather his overuse of an index finger point that made him look as if he was always scolding the audience. Audio engineer Jen Munson points out that sound technicians brought down Dean's candidacy by isolating the scream from background noise and making him sound more ramped up (Avirgan and Malone 2016). Michael Lempert and Michael Silverstein (2012) suggest that Dean's scream was the culmination of a long line of political blunders that engendered a negative public opinion of his character. Given Trump's success in spite of much grander gaffes, we suggest another explanation: the scream mattered because Dean was judged as a politician, not as an entertainer.

Consider Trump's use of the pistol hand, a gestural signature brought over from the genre of entertainment. A comparison between this highly emblematic gesture and those normatively used by presidential candidates reveals the semiotic limitations of politics as usual (for an early discussion of emblematic or quotable gestures, see Kendon 1992). Trump's pistol hand is depictive, a show move, flashy; typical gestures for presidential politicians are pragmatic, emphatic, didactic. When Trump uses the pistol hand as a boardroom executive on The Apprentice, it conveys arrogance, sovereign power, and commanding force. Trump is the kind of guy who will never admit his own failures and rarely gives others a second chance. The gesture is understood through the iconicity of its production, where swiftness and precision accompany a gun shape in the striking down of an unworthy opponent. Yet the gesture is also playful: when Trump thrusts his hand forward to mimic the firing of a gun, he converts the sovereign force behind the performative "you're fired" into comedic appeal. He brings a child's pantomime of shooting an enemy - the use of hands to imitate the action of killing - to the firing of an adult in an entrepreneurial battle. The repeated image of a grown man unearthing child's play on nightly television to dismiss contestants functions as comedy, recalling Limon's (2000) symbiotic merger of punishing father and naughty son. Celebrity businessman and politician are brought together in a playful image of executive power.

Even more critically, Trump's hands differ from those of his competitors in that their movements are already established as part of the Trump brand. Trump's use of the pistol hand gesture can be traced back to his involvement with professional wrestling, an entertainment genre in which competitors craft a persona through a particular move that is packaged for fan consumption through staged comedic routines of violence. Trump has developed his own persona at WWE (formerly WWF and World Wrestling Entertainment) since at least 1988, when he brought 
WrestleMania IV to Trump Plaza in Atlantic City. Two weeks after The Apprentice debuted in 2004, Trump attracted media attention when he attempted to trademark the pistol hand gesture together with the catchphrase "You're Fired!" (McLeod 2005). The news item was viewed as laughable by both journalists and fans, who marveled at the audacity of Trump for thinking he could trademark such a common (and in this case, comedic) expression, much less a movement of the human body. Yet Trump's attempt was consistent with branding practices in professional wrestling, where performers claim ownership to gestures, nicknames, and wrestling moves to advance their celebrity character. In fact, Trump's campaign slogan "Make America Great Again," which he trademarked in 2015 at the start of his presidential run, follows from his earlier promise in professional wrestling venues to "make WWE great again." Trump's reduction of competitors to nicknames like "Low Energy Jeb," "Little Marco," "Lyin' Ted," "Pocahontas," and "Crooked Hillary" is a comparable branding tactic used for decades in this industry (although otherdirected instead of self-directed), as is his use of impersonation, which we analyze below as a nicknaming practice waged in the modality of gesture.

Trump has also imported tactics from the world of professional beauty pageants, a business he was likewise involved in for over a decade. His running commentary on the attractiveness of female adversaries recalls the judging rituals associated with pageant culture. Of note are his comments regarding Republican primary competitor Carly Fiorina ("Look at that face! Would anyone vote for that?"). Such comments demonstrate some of the accepted ranking practices found in beauty pageant culture. Beauty competitions do for femininity what wrestling competitions do for masculinity: they create a world of gestural performance based on an exaggerated and idealized notion of gender. They are about style not content, a point exemplified by the interview portion of many pageants. Contestants perform silently before the judges for hours in the bathing suit and evening gown competitions but are then given twenty seconds to answer a question. Trump's importation of ranking practices into insults launched at political competitors illustrates his ability to surpass unspoken rules of decency by reframing his behavior as speaking the truth and rejecting the culture of political correctness. After calling attention to physical features of women, Trump declares to the media, "I respect women, I love women, I cherish women," with no apparent awareness that such behavior might be perceived as misogynist. For some, his beauty rankings offer a funny pushback to political correctness and a no-nonsense display of campaign toughness; for others, it is simply unbelievable.

Like all depictive gestures, Trump's signature move exemplifies a form of metonymy, a semiotic process that reduces a whole to its parts (Mittelberg and Waugh 2014). One of the clearest ways to understand metonymy as social practice is through the concept of celebrity brand. According to rhetorician Robert Hariman (1995), "To become a celebrity, one has to master and distinguish oneself within a rhetoric of gestures-virtually every star has a defining gesture or gestural effect" $(80-81)$. This is a practice intensified by digital media: politicians become fragments of bodies and voices spread daily across thousands of media platforms. Their every step is converted into digital material recontextualized for different sectors of a consuming audience. Hariman views today's fragmentation of the body as continuous with courtly culture, where royals manifest sovereign power 
through looks and poses. The branding of US presidential politicians through gestural metonymy-for example, Nixon's double-V victory gesture, Clinton's thumbs up gesture, Obama's fist bump, Merkel's diamond-is thus a contemporary version of an old practice. Yet many of these gestures differ from Trump's pistol hand in that the media is primarily responsible for granting them their significance. Although politicians often come to embrace the brandings attributed to them, there is little evidence in the historical record of candidates actively crafting emblematic gestures in their campaign speeches as indexical of political persona, as in the case of Trump.

Trump's gestures are part of a complicated mediation of Trump's celebrity image as it relates to his overall brand. Trump is known as a famous figure with a long career of entertaining the mass US audience through performative humor. His humor works because it incorporates that central Bakhtinian trope called vulgarity. In Trump we find a Rabelaisian character that deploys bawdy humor to entertain his audience. He provides carnivalesque moments as he pokes fun at other candidates, at their bodies, at their fluids, at their stiffness. Like Rabelais, Trump understands that crude humor has the power to bring down the princely classes-aka, the political establishment-as well as anyone who opposes him. He uses it to advance the "antipolitics politics" that has been building in the US public sphere since at least the early 1990s. Viewers stay amazed by Trump's expressions of physical disgust regarding the embodiment of others, whether in reaction to Megyn Kelly's menstruation, Hilary Clinton's toilet behaviors, or Marco Rubio's sweating. By reducing his opponents to bodily behaviors, Trump assumes the position of a Rabelaisian clown, bringing down the old guard by exposing the grotesque body beneath. This strategy is key to understanding Trump's gestural depictions, the subject of the next section.

\section{Gesture}

What is it about Trump's public movements that allow him to appear comedic yet serious enough to become the Republican Party candidate? We turn now to the power of gesture as a modality particularly suited to the accomplishment of comedic insult in mediatized political forums. True to entertainer type, Trump violates many of the normative bodily standards of presidential propriety expected for the political stage. Most notably for our purposes, he produces emblematic gestures as self-branding, performs a contrastively large gestural space, and enacts reductive gestural depictions of his opponents by framing their bodies as grotesque. When Trump exposes the "truths" of the body as part of his comedic routine, he exploits a widely circulating language ideology in the United States: the body is thought to speak its own truth beyond the ephemerality of words. Trump's opponents interpret his gestures as truth of discriminatory attitudes that exist beyond the comedic act; his supporters read the same gestures as truth that he is not afraid to express his opinions, even when confronted with the censorship ideals of political correctness. Trump's bodily expressions thus enable plausible deniability by defying standardized interpretation. It is the body's ambiguity that calls forth media spectacle. When Trump rejects the offending meanings his 
opponents proffer, the media responds by giving credibility to divergent interpretations, rebroadcasting the performance across the news cycle as commentators debate gestural meaning (cf. Boyer and Yurchak 2010 on media reception of Obama's facial scratch). The spectacle has been created, but the entertainer politician emerges unscathed.

Depictive gestures such as enactments are formed by incorporating bodily knowledge of the social world, abstracting qualities exhibited by the targeted object such as height, weight, shape, and speed (LeBaron and Streeck 2000; Mittelberg and Waugh 2014; Streeck 2008a). Yet because this incorporation is selective, such bodily acts also produce contextualized meaning, exemplifying an ideologically saturated semiotic process known as indexicality (Bucholtz and Hall 2016). For instance, Trump's use of a firing squad gesture (see Figure 3) does not merely resemble the action of execution; it also unites moral and material worlds to critique Obama as losing ground, being weak in confronting terrorism, and making poor deals. When imitating a firing squad in a campaign speech in Greensboro, North Carolina, Trump registered a critique against the US government for exchanging five Guantanamo prisoners for Sergeant Bergdahl, a US army soldier captured in Afghanistan and thought by some to be guilty of desertion if not treason. "In the old days," Trump says, "it would have been-"; then he pauses to enact the sideways firing of a rifle as if part of a firing squad. When performing this same routine in a campaign speech in Doral, Florida, he repeats the gesture twice before professing his love for the Second Amendment. The gesture thus materializes both a time period and a moral position that preceded political correctness, when punishment for betrayal was acceptable practice. In this way, gestural enactments have much in common with what linguists such as Niko Besnier (1993) and Deborah Tannen (1986) have identified for reported speech: they are citations disguised as quotes that "leak" the citer's own imagining of social life and the ideologies that constitute it. Even the most conventionalized of depictive gestures inscribe broader societal discourses within the affordances of the body, transforming these discourses into an action.

For many viewers, the exaggerated displays that we outline in this section recall a moment-to-moment reality television star whose character role is built on spontaneity. Linguist Jennifer Sclafani has observed that Trump is "turning political discourse into reality TV," noting in particular the way he uses large gestures to remind viewers of his "big personality" (Atkin 2015). Sclafani is not alone in noticing an iconic relationship between Trump's gestures and Trump's personality: certainly, the editorial cartoons mentioned above play off this reading, as does widely circulating metacommentary on the meaning of Trump's gestures (BBC News 2016; Bloomberg Politics 2016; Civiello 2016; Rozzo 2016). Donald Trump has done for presidential campaigns what Jerry Springer did for tabloid talk shows: he has inserted a level of lowbrow drama, humor, and violence into the genre through exaggerated appeals to the body. Trump's body matters to advocates as well as opponents. To advocates, Trump's gestures suggest a man who is spontaneous and real instead of scripted. He is an unplanned man, even an honest man, who tells it how he sees it. To opponents, Trump's gestures suggest a man who is vulgar if not offensive. They reveal a different sort of spontaneity: a buffoon, even a fake, who only poses as a politician. 


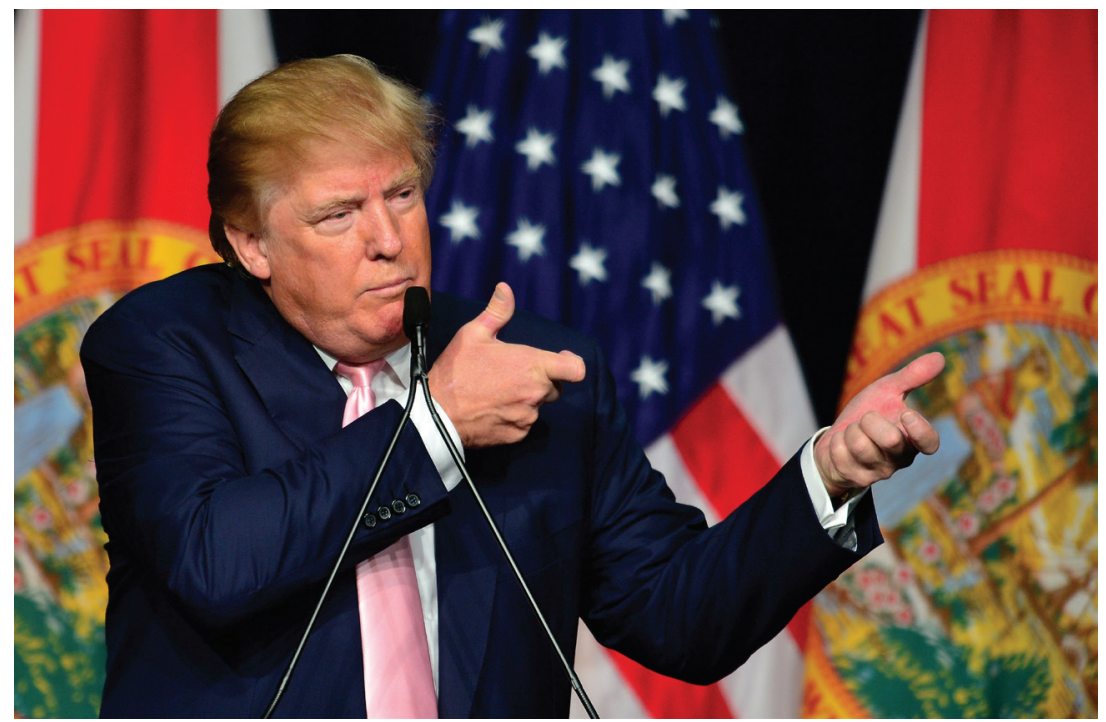

Figure 3: Trump's Firing Squad gesture, Ghetty Images.

Trump exploits both kinds of attention when he uses bodily performance to characterize the less competent behaviors of political opponents. This strategy is an important one for an entertainer new to politics; above all, it enables Trump to reposition the job experience of his opponents as a drawback instead of a qualification. Tellingly, the most common enactments used by Trump for established politicians involve the performance of small gestural space. Although gesture scholars often discuss gestural space (the personal space appropriated in the execution of gesturing) as a matter of individual, cultural, and contextual concerns (McNeill 1992; Sweetser and Sizemore 2008), Trump's essentializing poses, repeated multiple times across campaign speeches, make it clear that gestural space can also be a matter of ideology (Hoenes del Pinal 2011; R. L. Lakoff 1992). They include the performance of a hunched body reading from a script for Hillary Clinton (see Figure 4), a stiff upper body for Mitt Romney (see Figure 5), and a huddled sleeping body for Jeb Bush (see Figure 6).

With depictions like these, Trump uses gestural space to drive home his critique of the political establishment. The discourse goes something like this: politicians are people who do not act, who are not business people, and who do not know real risk. When mapped onto a restricted torso, an elite political class materializes as bookish, stiff, and lackluster. The mimicked gestural spaces of his opponents contrast sharply with the gestural space Trump inhabits in his own persona. Excessive gestural space is often negatively associated with tropic representations of social groups (e.g., the flamboyant gay man, the sassy black woman), but Trump uses gestural excess to convey the impression he is a new kind of politician, unconstrained by petty rules and competent at accomplishing daunting tasks. His performance of a large gestural space thereby becomes acceptable, if not politically desirable. In effect, Trump has expanded the space allowed for political gesture (at least for outsider politicians like himself). 


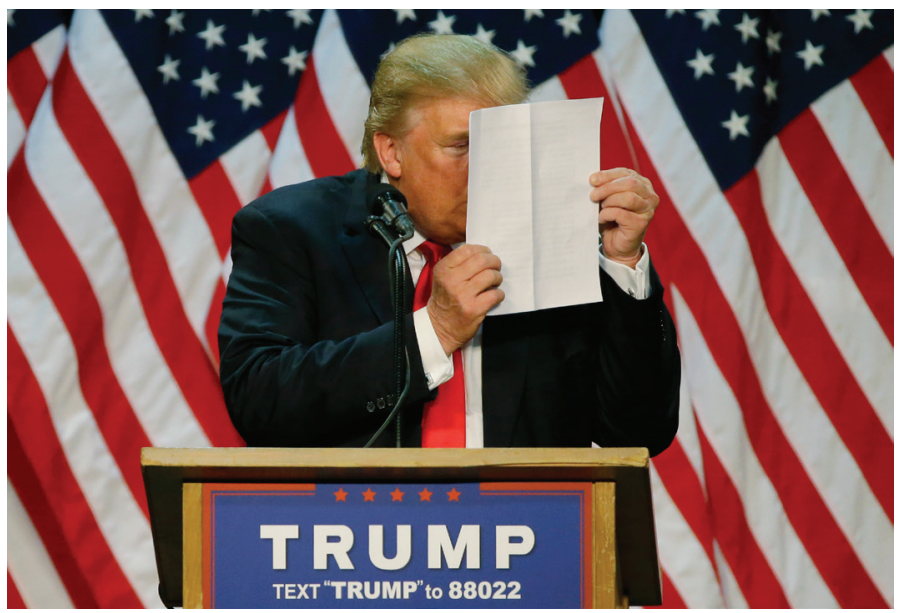

Figure 4: Script-Reading Hillary, Associated Press Images.

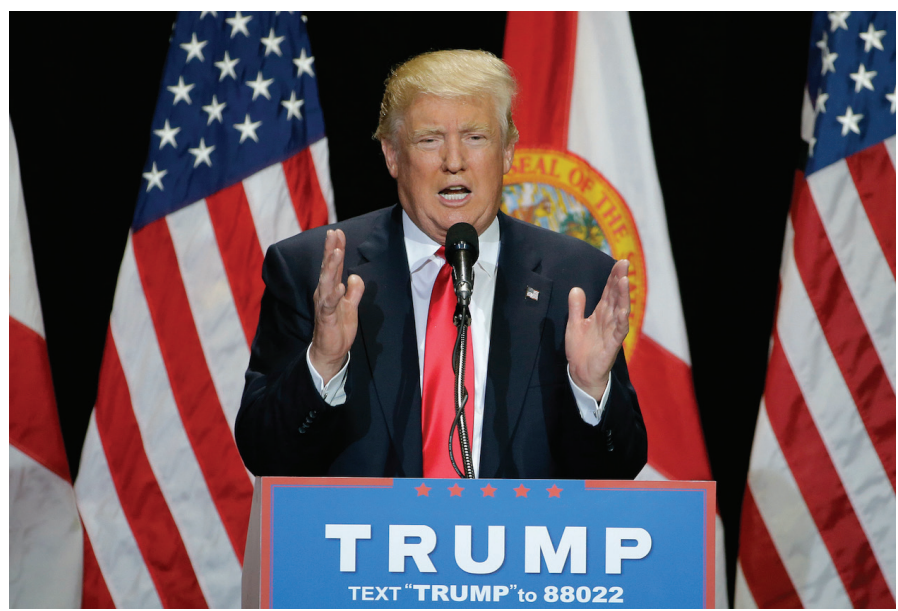

Figure 5: Stiff Mitt Romney, Associated Press Images.

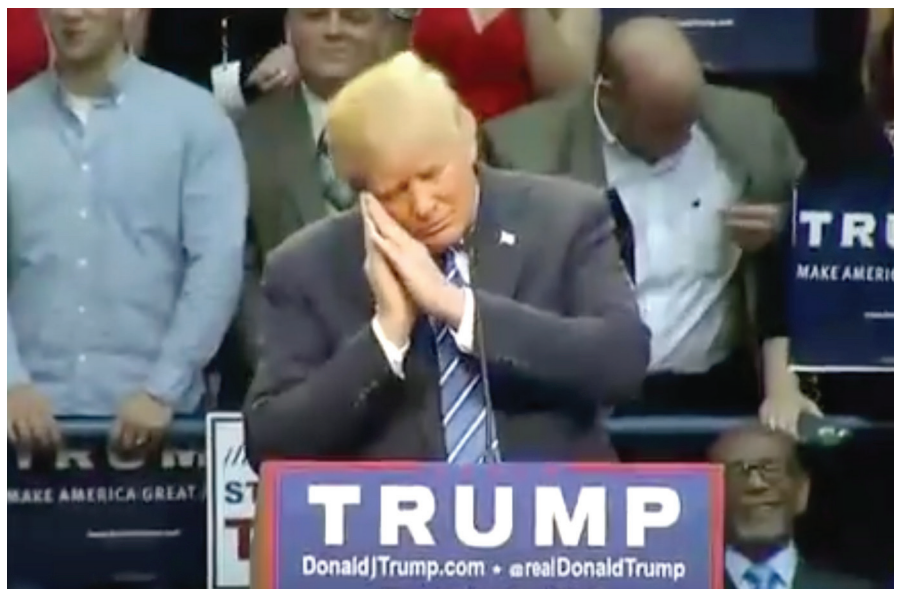

Figure 6: Low Energy Jeb, CBS North Carolina. 
The gestural enactments outlined here function similarly to nicknames, crafting a metonymic representation of the referent that purportedly captures some essential truth. In the early anthropological literature, nicknames were discussed as part of the brick and mortar of local social systems (Pitt-Rivers [1954] 1961; Cohen 1977; Gilmore 1982; McDowell 1981). But nicknames also form part of an oblique naming system that belongs to comedic insult and "can be understood as a play upon form: that is, as a joke, or rather, the punchline of a joke" (Blok 2001: 157). In other words, the purpose of a nickname is not just to mock but also to entertain. In the new political process orchestrated by a comedic billionaire, the public watches as Trump rolls out nicknames for each successive opponent. The gestural nicknames are initially coarticulated with verbal nicknames such as "Low Energy Jeb" but later take on their own independence as detachables. In Bakhtinian perspective, this naming process accomplishes something important. Through metonymic reduction, nicknames connect the subject to the grotesque body, thus becoming comic and provoking hilarity. By mocking the subject and making the named person look foolish, nicknames give special powers to the provider. After all, the one who is the master of nicknaming is the person declaring the public secret.

We turn now to three widely mediatized gestural enactments that display Trump's antagonism to political correctness by invoking discourses of disability, class, and race. These enactments are more elaborate and extended than the nicknames performed above, but they similarly reduce a target perceived as an opponent to an action of the body: the Wrist-Flailing Reporter, the Food-Shoveling Governor, and the Border-Crossing Mexican. Trump's bodily parodies deliver the message that he rejects progressive social expectations regarding how minority groups should be represented. In each case, the media responded by moving away from an initial critical stance to a discussion of the meaning conveyed by Trump's body.

\section{The Wrist-Flailing Reporter}

One of the most cited of Trump's gestural spectacles involves a full-body enactment of Washington Post reporter Serge Kovaleski. Trump quoted Kovaleski on the campaign trail as saying fourteen years earlier that Muslims were celebrating in response to 9/11, an allegation Kovaleski denied. At a rally in Myrtle Beach, South Carolina, Trump responded to this denial by framing Kovaleski as one of many "incompetent dopes" together with the president, politicians, and journalists. The theme of the speech is thus about incompetence. As with the firing squad example, Trump's speech is particularly focused on the ineptitude wrought by political correctness, which in his view keeps politicians from speaking the truth and doing the right thing. But Kovaleski also happens to be afflicted by a muscular condition that involves contracture of the body muscles and joints. In his gestural depiction of Kovaleski, Trump transforms a discourse of incompetence into the action of flailing, limp wrists (see Figure 7a-c) and produces a multimodal image depictive of disability. (Due to space constraints, the images included in Excerpts 1 and 2 capture only a single frame of the extended depictive gestures used in these enactments; Trump also uses a number of pragmatic and interactive gestures that we do not notate in the transcripts.) 
Excerpt 1: The Wrist-Flailing Reporter

Written by a nice reporter. Now the poor guy, you gotta see this guy. (Mimics Kovaleski's voice and actions.) ["Uhaaaaaaaaaaa I don't know what I said uhaaaaa!! ] [I don't remember!"] ${ }^{7 b}$ He's going like [“I don't remember uh doh, maybe that's what I said." ]" ${ }^{7 c}$ (He returns to his own voice, shouting.) This is fourteen years ago he still- They didn't do a retraction? Fourteen years ago, they did no retraction.

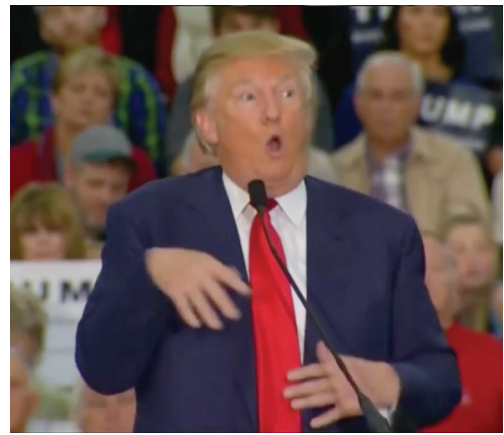

Figure 7a:

Wrist-Flailing Reporter, RightSide Broadcasting.

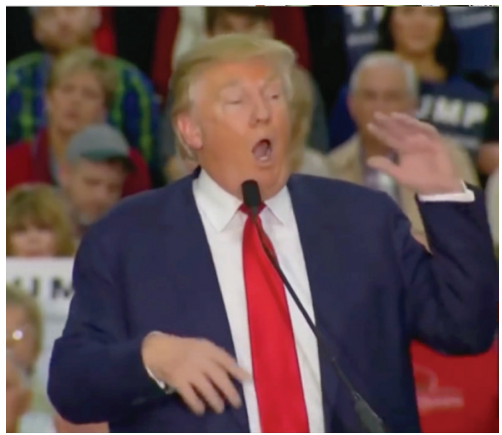

Figure $7 \mathbf{b}$ :

Wrist-Flailing Reporter, RightSide Broadcasting.

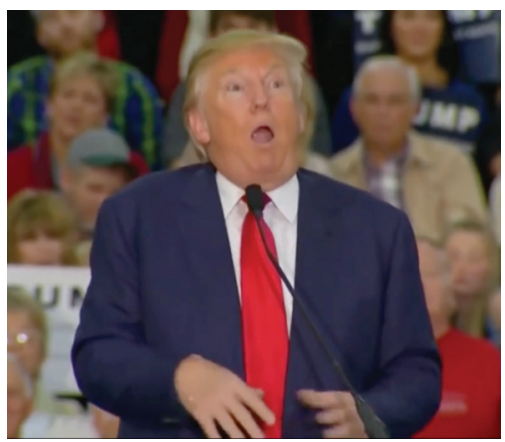

Figure 7c:

Wrist-Flailing Reporter, RightSide Broadcasting.

In this excerpt, a perceived opponent is metonymically represented by a flailing bodily habitus (uncontrolled, limp-wristed movements), facial contortions (rounded o-lip), and incoherent speech (loud elongated vocalizations produced in the back of the throat). The depiction produces a recognizable emblem in US popular culture of physical and mental disability. Emblematic gestures may sometimes be used in place of speech to displace responsibility for taboo topics (Brookes 2011), but the highly negative public response to Trump's enactment suggests that this gesture cannot easily escape its performative associations. Yet Trump was nevertheless able to deny this interpretation in a follow-up statement: "I have no idea who Serge Kovaleski is, what he looks like, or his level of intelligence. I merely mimicked what I thought would be a flustered reporter trying to get out of a statement he made long ago. I have tremendous respect for people who are physically 
challenged." Trump thus retroactively characterizes his act as "mimicry," but he denies the public interpretation of that mimicry as a biographically specific impersonation targeting a category of disabled persons. Although the media response was initially condemning, Trump's defense transformed the critique into an interpretive discussion. Regardless of the relationship between the performance and the object depicted, Trump moved political discourse to a new place by highlighting gestural ambiguity through comedic routine.

\section{The Food-Shoveling Governor}

A second gestural enactment that caught the attention of the media is Trump's depiction of Ohio governor John Kasich shoveling a pancake into his mouth (see Figures $8 \mathrm{a}-\mathrm{d}$ ), which was performed at a rally in Warwick, Rhode Island, in response to widely circulated images of Kasich eating at a New York restaurant. The depiction invites comparison with the Wrist-Flailing Reporter, except that it draws from discourses of social class instead of disability. (Again, the images below are provided as single-frame examples of the main gestural depictions used in the excerpt.)

Excerpt 2: The Food-Shoveling Governor

Now you look at Kasich, I don't think he knows what- you know, did you see him? He has a news conference [all the time when he's eating. ${ }^{\mathrm{FSh}}$ (Crowd laughs.) I have never seen a human being eat in such a disgusting fashion. (Crowd laughs and cheers.) I'm always telling my young son Barron, I'm saying — and I always with my kids, all of 'em- [I'd say, "Children, small little bites, ] ${ }^{\mathrm{SB}}$ small." (Crowd laughs.) This guy [takes a pancake] ${ }^{\mathrm{BP}}$ and he's [shoving it in his mouth] ${ }^{\mathrm{FSt}}$ you know.

(Crowd laughs and cheers.) It's disgusting. Do you want that for your president? I don't think so. (Crowd boos “no!") I don't think so. It's disgu- honestly, it's disgussting.

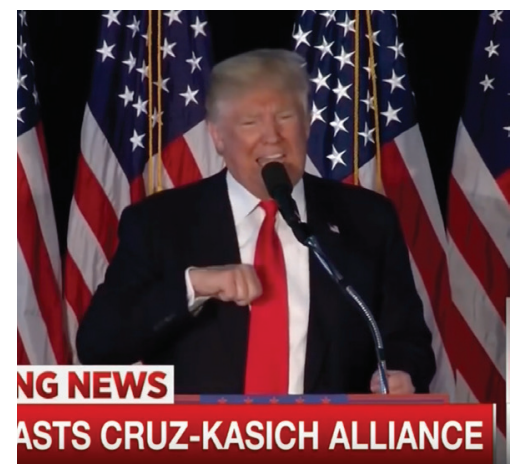

Figure 8a:

Food-Shoveling gesture (FSh), MSNBC.

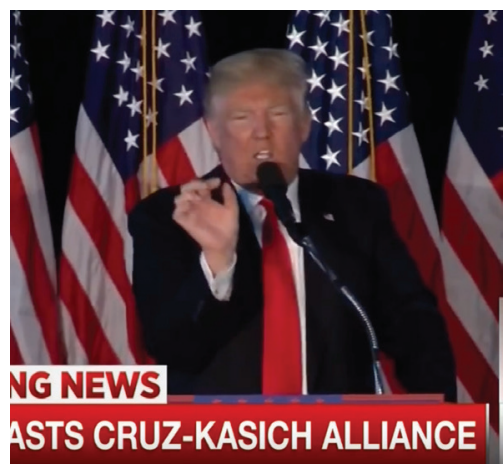

Figure 8b:

Small Bites gesture (SB), MSNBC. 


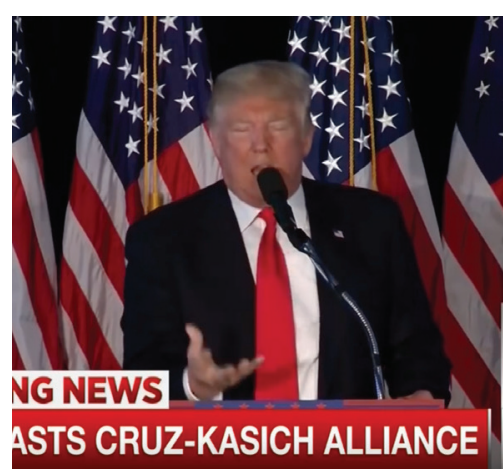

Figure 8c:

Big Pancake gesture (BP), MSNBC.

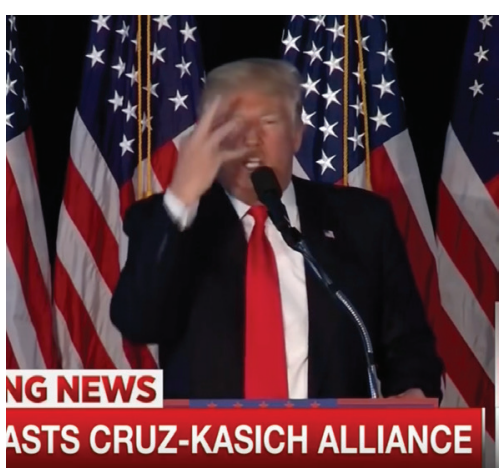

Figure 8d:

Food-Stuffing gesture (FSt), MSNBC.

In this dramatization of Kasich's table manners, we are again confronted by a display of discomfort with nonnormative bodies. It is well known that Trump avoided the fray of vernacular embodiment on the campaign trail by rarely eating with locals, even though this activity is expected of presidential candidates. In fact, Trump is famous for eating even fast food with a knife and a fork. Anthropologists familiar with the work of Norbert Elias (1982) and Pierre Bourdieu (1982) on the importance of table manners to class distinction would recognize Trump's enactment as a veiled class assault: Kasich is a slob, a low life, a "subhuman" who would have difficulty being presidential. Trump, in contrast, is a man who teaches his children to exhibit good manners and eat politely in "small bites." When returning to this same routine later in the speech, Trump illustrates that even his youngest child (named Barron) knows that Kasich's behavior is wrong: "He said, 'Daddy, look!' I said, 'Don't watch. Little bites, little bites." Trump performs versions of this routine in at least four other campaign venues. Each time, as in the above excerpt, the crowd's laughter, cheers, and boos suggest alignment with Trump's perspective, even as he portrays Kasich as eating like a pig.

We again turn to the power of entertainment to understand the rhetorical effects of Trump's display. His stint on Kasich incorporates recognizable techniques from impromptu stand-up comedy. He performs the voices of others as prompts for mockery (his young son), involves the audience through call and response ("Did you see him?" "Do you want that for your president?"), uses a repetitive verbal refrain to thematize a mocking stance toward his target ("disgusting"), and employs the method of abjection by calling attention to another candidate's eating habits. Moreover, Trump creates the caricature of Kasich by assuming the roles of punishing father and naughty son, with Kasich in the role of the latter. In sum, these cross-modal stylizations provide the ground for the rhetorical call-and-response that comedic routine relies on while also signaling the inability of Kasich to perform competently as president.

Trump's one-upmanship form of humor reinforces his superiority to those he critiques, a process noted by laughter theorist Henri Bergson (1921) almost a hundred years ago. His gestural enactments produce the comedic callousness that is central to his political persona. The emblematic gesture that accompanies "You're 
Fired" lacks the power to be felicitous when Trump utters it in a political context, making it all the more comical for its absurdity. This explains why commentators posting about Trump's pistol hand on video sharing sites such as YouTube indicate a playful enjoyment of the gesture even when they do not necessarily agree with its message ("Not a fan of him at all. But honestly, that was actually funny.") (Live Satellite News 2015). It also explains why audience members at a campaign rally in Madison, Alabama, break into uproarious laughter when Trump fires his pistol hand three times at a random plane flying overhead ("What is that? Oh. Uh oh, it's ISIS, get them down!"), and why audience members laugh in Manchester, New Hampshire, when Trump points to another plane and suggests it might be carrying Mexicans. As with the Kasich example, these are packaged comedy routines, cliché gags, shticks. If Trump brags about his ability to deliver a speech without a teleprompter ("I don't need those notes because I don't need notes. Aren't I lucky?"), it is because he knows how to exploit what is unfolding in the world around him as a comedic prompt. Specifically, he incorporates the immediate environment into the performance of his own comparative competence. Trump's gestural enactments, as with parody more generally, thus exhibit a dual indexicality that points to the teller of the joke as much as to its target (Hill 1999; cf. Hall 2005). They may denigrate a social group by linking them to stereotyped body movements, but they also point back to him as a fun-loving guy who breaks the rules to enjoy a good joke. In short, Trump's body becomes a spectacle that resembles stand-up comedy, where politically correct language and sensitive topics are breached for entertaining effects.

\section{The Border-Crossing Mexican}

Trump has developed a series of depictive gestures that coordinate with his promise to build a wall at the Mexican border. These depictions work together to construe Mexicans as bodies out of place. The "huuuge" wall that Trump performs in several campaign speeches-wide outstretched arms to illustrate width, tall upright arms to illustrate height, a sharp L-shaped drawing pattern to illustrate strengthpositions Mexicans as a wandering people who need to be stopped. Trump even performed a gestural enactment of Mexicans as "candy grabbers" at several venues when discussing outsourcing (with fingers pulling toward the palm), again suggesting a greedy people who put their hands in places they do not belong ("Mexico has been taking your companies like it's candy from a baby, right?"). With these and related gestures, Trump expresses disdain for individuals whose lives are structured around migration.

A prominent media spectacle during the Republican primary season was a video broadcast of Trump disembarking from his car, climbing through a fence to cross over a concrete structure, and walking across a field to enter the back door of a stadium surrounded by protestors in San Francisco, California. When he finally arrives at the podium, knowing that his actions are being followed in real-time on cable news, Trump leads his audience in laughter by comparing his trek to "crossing the border." His darkly satirical portrayal draws its humor from the absurd image of Trump the billionaire in the role of a border-crossing Mexican immigrant. This enactment differs from the previous two examples in that it is a reinterpretation of Trump's own bodily movements televised earlier. Yet the performance has 
all the elements of comedy. It turns something tragic and sad into something funny and absurd (Goldstein [2003] 2013). A privileged well-dressed body is reimagined in the role of impoverished migrant: Trump-the-immigrant crossing dangerous regions filled with protesters in order to get to his podium.

Circulating videos of the verbal and gestural enactments discussed in this section keep Trump at the forefront of national attention. As each day of the campaign passes, news consumers want to know: Who did Trump offend this time? Yet the question we pursue is a relatively uncharted area for gesture studies: How do Trump's bodily acts keep supporters as well as adversaries coming back for more? Scholars working on conversational interaction provide one possible answer by illustrating how gestural enactments elicit heightened displays of attention, build a form of shared common ground, enlist coparticipation, and provoke laughter (Sidnell 2006; Thompson and Suzuki 2014). This body of research offers empirical support to Bergson's early characterization of gesture as "something explosive, which awakes our sensibility when on the point of being lulled to sleep and, by thus rousing us up, prevents our taking matters seriously" (1921: 144). Perhaps it is true that Trump has become America's newest "guilty pleasure" (Grossman 2015), dominating newsrooms, comedy sketches, social media, classrooms, and everyday conversation. Through gestural stylization, Trump creates a spectacle to be consumed. It does not matter whether the spectacle is respected, simply tolerated, or even abhorred, the outcome remains the same: we keep on watching. The public's attraction to the political character known as Donald Trump is the subject of our third and final section.

\section{Spectacle}

The Trump empire brings together many of the elements analyzed by scholars as spectacle in late capitalism: hyperbole, casino capitalism, branding, simulacra, nostalgia, mediatization, excess, consumption, and vacuousness. Indeed, many of Trump's known interests and business endeavors are coincident with the thematic focus of influential spectacle theorists. Trump's engagement with professional wrestling recalls Roland Barthes's ([1957] 2009) essay on wrestling as "the spectacle of excess." His construction of nostalgic hotels like Trump Taj Mahal and Trump Castle Casino evokes Jean Baudrillard's (1988) theorization of simulacra and the hyperreal in postmodernity. The Republican primary debates could be seen as their own kind of simulacra, turned by Trump into a mass-mediated spectacle that was in many ways predicted by Guy Debord's ([1967] 1970) work on the increasing importance of the mediated image to the formation of social relationships in capitalism. David Harvey $(1990,2006)$ perhaps makes the most explicit connection between public space, capitalism, and spectacle when he speaks of the "mobilization of spectacle"-that is, the movement of capital to urban spaces in periods of intensified competition and entrepreneurialism, as we now understand to have happened in Las Vegas and Atlantic City, places shaped by Trump's hand. According to Harvey (2006, building on Sennett [1974] 1992), this mobilization serves to mask and disguise the fundamentals of class relations, bringing as its final scene a thorough depoliticization of these spaces. 
Trump as a branded commodity to be consumed — or rather, Trump ${ }^{\mathrm{TM}}$ - has entered politics in a way never seen before, as technological and institutional forces harness the power of Trump as old-school capitalist and entrepreneur of spectacle and escort his brand into the political spectrum. His ability to bring previously distinct forms of semiotic extravagance together (reality television, beauty contests, wrestling matches) and insert them into his candidacy for the most powerful position in the world is precisely what makes Trump a never-ending spectacle. It is perhaps redundant to remind the reader that Trump's business narrative is everywhere saturated with examples of late-capitalist excess-restaurants that offer allyou-can-eat menus; investments that earn money through bankruptcy; branding schemes that are several times removed from the brand itself. It seems that we have decisively arrived in the era of late capitalism critiqued by each of the above theorists for fetishizing style over content and for ultimately serving as a depoliticizing force.

Yet it is style, of course, that makes spectacle entertaining. In this article, we have tracked Trump's use of comedic style as it informs his gestural behaviors on the campaign trail, where he reduces diverse forms of social complexity to buffoonish movements of the human body. Trump's gestural spectacles in public, even if they earn him more adversaries than supporters, maintain steady reception as they incite landmark media coverage. As we know from other examples of negative spectacles, the gesture and its source can maintain media coverage in spite of the message. We are reminded of the global response to the widely circulated spectacle of US soldier Lynndie England's thumbs up and pistol hand gesture, which she performed before naked Iraqi detainees at Abu Ghraib prison during the US-led Iraq war. This gesture, initially associated with torture and institutional military excess, was later transformed into hilarity through its mediatization on a British visual blog website (see Hristova 2013). Over the course of a few weeks, England gradually became a victim of her own gesture as participants began to upload photographs of unattractive people in unglamorous occupations "doing a Lynndie." Even the most perverse of depictive gestures-in this case, a "photo cliché" that instances a dark moment in US history-is easily fetishized as comedic spectacle, particularly when subjected to the digitized imaginings of citizen photographers. Gestures are certainly open to a variety of ideological interpretations (cf. Alim and Smitherman 2012 on Obama's fist bump as a "terrorist fist jab"), and we expect Trump's gestures to be cast in new ways as the campaign moves forward. But if these bodily acts are ultimately interpreted as entertainment rather than other possibilities (ableist, classist, racist, nativist, sexist, etc.), then it is possible that even Trump's most offending gestures can be depoliticized.

Yet Trump is also a vernacular spectacle (cf. Androutsopoulos 2010), a multimediated image fueled by linguistic and gestural features that are densely indexical of New York City. The 2016 presidential election is one of the first in many decades where a New York vernacular style is as much an asset as it is a hindrance, contributing to positive as well as negative media attention. Both Donald Trump and Bernie Sanders share styles reminiscent of less elite boroughs, specifically Brooklyn and Queens. Perhaps this turn of events was encouraged in the aftermath of 9/11, when Rudy Giuliani famously declared, "We are all New Yorkers now." The nation saw and heard-and even came to respect and possibly 
idolize - what had previously been considered a brash New York style, opening the potential for the rise of both Trump and Sanders. In fact, at several junctures in the primary election cycle, Trump invited what he believed to be antiestablishment Democratic voters supporting the progressive candidate Sanders to join his campaign. The ideological gap that separates these two candidates should not be underestimated. While Trump may be ushering in a depoliticized era bereft of content, our sense of things is that Sanders added in content previously missing. But this would be another article, and we are trying here to understand what keeps Trump from losing ground in spite of a relative lack of substance and many rhetorical gaffes.

In her ethnography No billionaire left behind, Angelique Haugerud tracks the rise of political satire in an American public sphere that lacks deep investigative reporting and increasingly relies on "personality more than issues, style more than substance, and tactics more than context" (2013: 189). She focuses on a group of satirical activists who began appearing at political events at the turn of the twentyfirst century under the title "Billionaires for Bush," precisely when the super-rich billionaire class began to attract attention. Haugerud poses the question: What follows "after satire"? We suggest that it is the comedic debauchery of Donald Trump that follows. His rise is the next logical chapter of a hypermediatized politics that lacks content, sells itself as entertainment, and incorporates comedic stylistics so as to immunize itself from critique. In contrast to the parodies discussed by Haugerud, Trump's performances depend on his self-proclaimed successful billionaire status and alleged competence. We are hesitant to elevate Trump's programmed routines by calling them satire, but it is precisely their comedic effects that work for him as political entertainment.

We have written this article with some concern that our analysis will bring even more attention to the comedic and gestural techniques that have assisted Trump's rise, yet we also believe that there is much to be learned from the anthropological and linguistic insights expressed here. In our view, the benefits of revealing the processes through which Trump gained momentum outweigh the dangers of adding to his media presence. Shortly after the Republican primaries concluded, large naked statues depicting Trump's grotesque body began to appear in urban public areas around the country, perhaps in an attempt to confront Trump with his own comedic weaponry. This article is meant to be similarly confrontational in its exposition of the value accrued by Trump's bodily behaviors. Trump has done what a previous generation thought impossible: he has turned a billionaire caricature into a wildly popular political brand. During the Republican primaries, Trump repeatedly promised the public that he would "become presidential," cease his whack-a-mole tactics against adversaries, and bring respectful demeanor back to the campaign. As we conclude this article two months before the national election, we have yet to see Trump's promise materialize. But we are struck by the words he used at a campaign rally in Harrisburg, Pennsylvania: "At some point I'm going to be so presidential that you people will be so bored." Perhaps Trump has it right. Now that the American public has taken its seat in the perversely compelling theater that we have outlined throughout this article, politics as usual cannot easily follow. 


\section{Acknowledgments}

The authors are deeply grateful to HAU editors Giovanni da Col, Amira Mittermaier, and Michael Lambek for their quick and generous shepherding of this paper. We would also like to express our appreciation to five anonymous reviewers, editors Molly Mullin, Sean Dowdy, and Michelle Beckett for their keen insights, and the many colleagues who provided feedback along the way: Niko Besnier, Anton Blok, Barry Brummett, Mary Bucholtz, Alison Cool, Kristen Drybread, Kate Goldfarb, Candy Goodwin, Tamara Hale, Arlene Hall, Leo Hall, Angelique Haugerud, Olivia Hirschey, Lonia Jakubowska, Carla Jones, Velda Khoo, Peter Koester, Michael Lempert, Laura Michaelis-Cummings, Carole McGranahan, Arielle Milkman, Chris Morris, Lindsay Ofrias, Nick Remple, Richard Sandoval, Muhammad Sheeraz, Magda Stawkowski, Jürgen Streeck, Irina Wagner, and Sydney White.

\section{Appendix: Figure Permissions}

Figure 1a-b: Trump's Pistol Hand gesture. Raleigh, North Carolina, 12/4/15. Reprinted with permission from CBS North Carolina.

Figure 2: Trump's Pistol Hand gesture. The Apprentice, 2006. Reprinted with permission from Ghetty Images.

Figure 3: Trump's Firing Squad gesture. Doral, Florida, 10/23/15. Reprinted with permission from Ghetty Images.

Figure 4: Script-Reading Hillary. Eugene, Oregon, 5/07/16. Reprinted with permission from Associated Press Images.

Figure 5: Stiff Mitt Romney. Tampa, Florida, 6/11/16. Reprinted with permission from Associated Press Images.

Figure 6: Low Energy Jeb. Raleigh, North Carolina, 12/4/15. Reprinted with permission from CBS North Carolina.

Figure 7a-c: The Wrist-Flailing Reporter. Myrtle Beach, South Carolina, 4/25/16. RightSide Broadcasting. Reprinted under fair use.

Figure 8a-d: The Food-Shoveling Governor. Warwick, Rhode Island, 11/24/15. MSNBC. Reprinted under fair use.

\section{References}

Alim, H. Samy, and Geneva Smitherman. 2012. Articulate while Black: Barack Obama, language, and race in the U.S. New York: Oxford University Press.

Andrejevic, Mark. 2004. Reality TV: The work of being watched. Boulder, CO: Rowman and Littlefield.

Androutsopoulos, Jannis. 2010. "Localizing the global on the participatory web." In The handbook of language and globalization, edited by Nikolas Coupland, 203-31. Malden, MA: Wiley-Blackwell.

Atkin, Emily. 2015. “What language experts find so strange about Donald Trump.” Think Progress.

http://thinkprogress.org/politics/2015/09/15/3701215/donald-trump-talks-funny-2/. 
Avirgan, Jody, and Clare Malone. 2016. "Why the Dean scream sounded so different on TV." FiveThirtyEight Podcasts. http://fivethirtyeight.com/features/ why-the-dean-scream-sounded-so-different-on-tv/.

Bakhtin, Mikhail. 1984. Rabelais and his world. Translated by Helene Iswolsky. Bloomington: Indiana University Press.

Barthes, Roland. (1957) 2009. Mythologies. Translated by Annette Lavers. London: Vintage Classics.

Baudrillard, Jean. 1988. America. London: Verso.

Bavelas, Janet Beavin, Nicole Chovil, Douglas A. Lawrie, and Allan Wade. 1992. "Interactive gestures." Discourse Processes 15 (4): 469-89.

BBC News. 2016. "What Trump's hand gestures say about him.” http://wwws/election-us-2016-37088990.

Bergson, Henri. 1921. Laughter: An essay on the meaning of the comic. Translated by Cloudesley Brereton and Fred Rothwell. New York: The Macmillan Company.

Besnier, Niko. 1993. "Reported speech and affect on Nukulaelae Atoll." In Responsibility and evidence in oral discourse, edited by Jane H. Hill and Judith T. Irvine, 161-81. Cambridge: Cambridge University Press.

Blitt, Barry. 2016. "Bad reception.” New Yorker, February 1.

Blok, Anton. 2001. Honour and violence. Cambridge: Polity Press.

Bloomberg Politics. 2016. “Donald Trump's hand gestures: A huge list.” http://www.bloomberg. com/politics/videos/2016-04-19/donald-trump-talks-with-his-hands-a-visual-dictionary.

Bourdieu, Pierre. 1982. Distinction: A social critique of the judgment of taste. Translated by Richard Nice. Cambridge: Harvard University Press.

Boyer, Dominic, and Alexei Yurchak. 2010. "American stiob: Or, what late-socialist aesthetics of parody reveal about contemporary political culture in the West." Cultural Anthropology 25 (2): 179-221.

Brookes, Heather. 2011. “Amangama amathathu 'The three letters': The emergence of a quotable gesture (emblem).” Gesture 11 (2): 194-217.

Brummett. Barry. 2008. A rhetoric of style. Carbondale: Southern Illinois University Press.

Bucholtz, Mary, and Kira Hall. 2016. "Embodied sociolinguistics." In Sociolinguistics: Theoretical debates, edited by Nikolas Coupland. Cambridge: Cambridge University Press.

Burke, Peter. 1978. Popular culture in Early Modern Europe. New York: Harper and Rowe.

Chun, Elaine W. 2004. "Ideologies of legitimate mockery: Margaret Cho's revoicing of Mock Asian.” Pragmatics 14 (2): 263-89.

Civiello, Mary. 2016. “The brilliance behind Donald's Trump's wild hand gestures.” Fortune, April 30. http://fortune.com/2016/04/30/donald-trump-hands/.

Cohen, Eugene N. 1977. "Nicknames, social boundaries, and community in an Italian village." International Journal of Contemporary Sociology 14: 102-13. 
The Daily Show with Trevor Noah. 2016. Did Donald Trump call for Hillary Clinton's assassination? August 10.

http://www.cc.com/video-clips/4p1qbk/the-daily-show-with-trevor-noah-did-donaldtrump-call-for-hillary-clinton-s-assassination-.

Debord, Guy. (1967) 1970. The society of the spectacle. Translated by Fredy Perlman and Jon Supak. Detroit: Black and Red.

Duffy, Margaret E., and Janis Teruggi Page. 2013. "Does political humor matter? You betcha! Comedy TV's performance of the 2008 Vice Presidential debate." Journal of Popular Culture 46 (3): 545-65.

Eggers, Dave. 2016. “Could he actually win?' Dave Eggers at a Donald Trump rally." Guardian, June 17. https://www.theguardian.com/books/2016/jun/17/could-he-actually-windave-eggers-donald-trump-rally-presidential-campaign.

Elias, Norbert. 1982. The civilizing process. Vol. 1, The history of manners. Translated by Edmund Jephcott. New York: Pantheon Books.

Ewen, Stuart. 1988. All consuming images: The politics of style in contemporary culture. New York: Basic Books.

Fleming, Luke, and Michael Lempert. 2011. "Introduction: Beyond bad words." Anthropological Quarterly 84 (1): 5-14.

Fussell, Paul. 1992. Class: A guide through the American status system. New York: Simon \& Schuster.

Gilmore, David D. 1982. "Some notes on community nicknaming in Spain." Man 17: 686-700.

Goffman, Erving. 1959. The presentation of self in everyday life. New York: Random House.

- 1961. Encounters: Two studies in the sociology of interaction. Indianapolis: Bobbs Merrill.

1974. Frame analysis: An essay on the organization of experience. New York: Harper and Row.

Goldstein, Donna M. (2003) 2013. Laughter out of place: Race, class, violence, and sexuality in a Rio Shantytown. Berkeley: University of California Press.

Goodwin, Marjorie Harness, and H. Samy Alim. 2010. 'Whatever (neck roll, eye roll, teeth suck)': The situated coproduction of social categories and identities through stancetaking and transmodal stylization." Journal of Linguistic Anthropology 20 (1): 179-94.

Grossman, Seth. 2015. "Donald Trump, our reality TV candidate." New York Times, September 26. http://www.nytimes.com/2015/09/27/opinion/donald-trump-our-realitytv-candidate.html?_r=0.

Hall, Kira. 2005. "Intertextual sexuality: Parodies of class, identity, and desire in liminal Delhi." Journal of Linguistic Anthropology 15 (1): 125-44.

Hariman, Robert. 1995. Political style: The artistry of power. Chicago: University of Chicago Press.

Harvey, David. 1990. The condition of postmodernity: An enquiry into the origins of cultural change. Oxford: Blackwell. 
2006. "The political economy of public space." In The Politics of Public Space, edited by Setha Low and Neil Smith. London: Routledge.

Haugerud, Angelique. 2013. No billionaire left behind: Satirical activism in America. Stanford: Stanford University Press.

Hill, Jane. 1999. "Language, race, and White public space." American Anthropologist 100 (3): 680-89.

History Channel. 2016. "How to lose the presidency: Howard Dean scream." Night Class. https://www.youtube.com/watch?v=yeZGePI62rU.

Hochschild, Arlie Russell. 2016. Strangers in their own land: Anger and mourning on the American right. New York: The New Press.

Hoenes del Pinal, Eric. 2011. "Towards an ideology of gesture: Gesture, body movement, and language ideology among Q'eqchi'-Maya Catholics.” Anthropological Quarterly 84 (3): 595-630.

Hristova, Stefka. 2013. “'Doing a Lynndie’: Iconography of a gesture.” Visual Anthropology 26: $430-43$.

Irvine, Judith T. 2011. "Leaky registers and eight-hundred-pound gorillas." Anthropological Quarterly 84 (1): 15-40.

Jaffe, Alexandra. 2000. "Comedic performance and the articulation of hybrid identity." Pragmatics 10 (1): 39-59.

Keevallik, Leelo. 2010. "Bodily quoting in dance correction." Research on Language and Social Interaction 43 (4): 401-26.

Kendon, Adam. 1992. "Some recent work from Italy on 'quotable gestures' (emblems)." Journal of Linguistic Anthropology 2 (1): 92-108.

—. 2004. Gesture: Visible action as utterance. Cambridge: Cambridge University Press.

Lakoff, George. 2016. "Understanding Trump." George Lakoff (blog). https://georgelakoff. com/2016/07/23/understanding-trump-2/.

Lakoff, Robin Tolmach. 1992. Talking power: The politics of language. New York: Basic Books.

LeBaron, Curtis, and Jürgen Streeck. 2000. "Gestures, knowledge, and the world." In Language and gesture, edited by David McNeill. 118-37. Cambridge: Cambridge University Press.

Lempert, Michael. 2011. "Barack Obama being sharp: Indexical order in the pragmatics of precision-grip gesture." Gesture 11 (3): 241-70.

Lempert, Michael, and Michael Silverstein. 2012. Creatures of politics: Media, message, and the American presidency. Bloomington: Indiana University Press.

Limon, John. 2000. Stand-up comedy in theory or, abjection in America. Durham, NC: Duke University Press.

Live Satellite News. 2015. "Donald Trump tells President Obama 'you're fired." https:// www.youtube.com/watch?v=RPfxyFMUd1k. 
Luhrmann, Tanya. 2016. “The paradox of Donald Trump’s appeal." Sapiens. http://www. sapiens.org/culture/mary-douglas-donald-trump/.

McDowell, John H. 1981. “Toward a semiotics of nicknaming: The Kamsá example.” Journal of American Folklore 94: 1-18.

McLeod, Kembrew. 2005. Freedom of expression: Overzealous copyright bozos and other enemies of creativity. New York: Doubleday.

McNeill, David. 1992. Hand and mind: What gestures reveal about thought. Chicago: University of Chicago Press.

Mittelberg, Irene. 2013. "Balancing acts: Image schemas and force dynamics as experiential essence in pictures by Paul Klee and their gestural enactments." In Language and the Creative Mind, edited by Mike Borkent, Barbara Dancygier, and Jennifer Hinnell, 325-46. Chicago: University of Chicago Press.

Mittelberg, Irene, and Linda Waugh. 2014. "Gestures and metonymy." In Body-LanguageCommunication, vol. 2, edited by Corneilia Müller, Alan Cienki, Ellen Fricke, Silva H. Ladewig, David McNeill, and Jana Bressem, 1747-66. Berlin: De Gruyter Mouton. On the Record. 2015. Fox News Channel, September 10.

Pitt-Rivers, Julian A. (1954) 1961. The people of the Sierra. Chicago: University of Chicago Press.

Rozzo, Mark. 2016. "Was this Robert De Niro role the inspiration for Trump's wild hand gestures?" Vanity Fair, April 18. http://www.vanityfair.com/news/2016/04/ robert-de-niro-donald-trump-wild-hand-gestures.

Scheper-Hughes, Nancy. 1992. Death without weeping: The violence of everyday life in Brazil. Berkeley: University of California Press.

Scott, James C. 1985. Weapons of the weak: Everyday forms of peasant resistance. New Haven, CT: Yale University Press.

Seizer, Susan. 2011. "On the uses of obscenity in live stand-up comedy." Anthropological Quarterly 84 (1): 209-34.

Sennett, Richard. (1974) 1992. The fall of public man. New York: W.W. Norton \& Company.

Sidnell, Jack. 2006. "Coordinating gesture, talk, and gaze in reenactments." Research on Language and Social Interaction 39 (4): 377-409.

Silver, Nate. 2016. “The mythology of Trump's 'working class' support.” FiveThirtyEight. http://fivethirtyeight.com/features/the-mythology-of-trumps-working-class-support/.

Singer, Mark. 1997. “Trump solo.” New Yorker, May 19.

Stallybrass, Peter, and Allon White. 1986. The politics and poetics of transgression. Ithaca, NY: Cornell University Press.

Streeck, Jürgen. 2008a. "Depicting by gesture." Gesture 8 (3): 285-301.

2008b. "Gesture in political communication: A case study of Democratic presidential candidates during the 2004 primary campaign." Research on Language and Social Interaction 41 (2): 154-86.

Sweetser, Eve, and Marisa Sizemore. 2008. "Personal and interpersonal gesture spaces: Functional contrasts in language and gesture." In Language in the context of use: 
Discourse and cognitive approaches to language, edited by Andrea Tyler, Yiyoung Kim, and Mari Takada, 25-51. Berlin: De Gruyter Mouton.

Taibbi, Matt. 2016. "How America made Donald Trump unstoppable." Rolling Stone, February 24 . http://www.rollingstone.com/politics/news/how-america-made-donald-trumpunstoppable-20160224.

Tannen, Deborah. 1986. "Introducing constructed dialogue in Greek and American conversational and literary narrative." In Direct and indirect speech, edited by Florian Coulmas, 311-32. Berlin: De Gruyter Mouton.

Thompson, Sandra A., and Ryoko Suzuki. 2014. "Reenactments in conversation: Gaze and recipiency." Discourse Studies 16 (6): 816-46.

Time. 2016. "Donald Trump: The rise of the rule breaker." Front cover, April 29. US News. 2016. "Editorial cartoons on the 2016 presidential elections." http://www.usnews.com/ opinion/cartoons/2015/01/30/editorial-cartoons-on-the-2016-presidential-elections.

Vance, J. D. 2016. Hillbilly elegy. New York: Harper Collins.

West, Darrell M., and John M. Orman. 2003. Celebrity politics: Real politics in America. Upper Saddle River, NJ: Prentice Hall.

Wheeler, Mark. 2013. Celebrity politics: Image and identity in contemporary political communications. Cambridge: Polity Press.

\section{Les mains de Donald Trump: Entertainment, gestuelle et spectacle}

Résumé : La transition, opérée par Donald Trump, d'homme d’affaire à candidat présidentiel populiste a laissé plus d'un commentateur perplexe. Cet article s'appuie sur les outils de l'anthropologie culturelle, linguistique et sur la théorie réthorique pour suggérer que le succès de la candidature de Trump tient en partie à sa valeur en tant que forme de grand divertissement comique. Nous examinons notamment la manière dont le style politique hors norme de Trump, son utilisation de la gestuelle pour critiquer le système politique et caricaturer ses opposants donnèrent un élan à sa campagne en la rendant spectaculaire. Des théoriciens poststructuralistes et néo-marxistes ont soutenu que le capitalisme tardif valorise le style au dépend du contenu: Trump donne un nouveau souffle à cette tendance. Le portrait-charge du monde sociopolitique que dessinent les gestes de Trump lorsqu'il s'attaque au politiquement correct ou lorsqu'il tente de désarmer ses adversaires, crée du capital visuel dans un univers politique contemporain médiatisé et sous-tendu par la célébrité.

Kira Hall is a linguistic anthropologist in the Department of Linguistics at the University of Colorado Boulder, with a courtesy appointment in the Department of Anthropology. In addition to the edited volumes Gender articulated: Language and the socially constructed self (Routledge, 1995) and Queerly phrased: Language, gender, and sexuality (Oxford, 1997), she has authored diverse journal articles and 
book chapters on the subject of language, identity, and embodiment in India and the United States.

Kira Hall

Department of Linguistics

295 UCB, Hellems Building

University of Colorado Boulder

Boulder, Colorado 80309-0295

USA

kira.hall@colorado.edu

Donna M. Goldstein is professor of cultural anthropology at the University of Colorado Boulder and author of Laughter out of place: Race, class, violence, and sexuality in a Rio Shantytown (University of California Press, 2003), winner of the 2005 Margaret Mead award. She writes within the fields of medical anthropology, anthropology of the environment, and Science and Technology Studies (STS) and is currently working on a project that examines the history of Cold War science and nuclear energy in Brazil.

\author{
Donna M. Goldstein \\ Department of Anthropology \\ 233 UCB, Hale Building \\ University of Colorado Boulder \\ Boulder, Colorado 80309-0233 \\ USA \\ donna.goldstein@colorado.edu
}

Matthew Bruce Ingram is a PhD student in the Department of Communication Studies at the University of Texas at Austin with a focus on rhetoric and language studies. His research draws from sociocultural and rhetorical understandings of embodiment to study how human actors use their embodied resources to represent themselves and others as well as make sense of their social worlds.

Matthew Bruce Ingram Department of Communication Studies

CMA 7.112, 2504A Whitis Avenue

University of Texas at Austin

Austin, Texas 78712-0115

USA

matthew.ingram@utexas.edu 